\begin{tabular}{|l|l|l||}
\hline \multicolumn{2}{|c|}{ PublisherInfo } \\
\hline \hline PublisherName & $:$ & BioMed Central \\
\hline \hline PublisherLocation & $:$ & London \\
\hline \hline PublisherImprintName & $:$ & BioMed Central \\
\hline \hline
\end{tabular}

\title{
Lots of splicing regulators
}

\begin{tabular}{|l|l|l||}
\hline \multicolumn{2}{|c|}{ ArticleInfo } \\
\hline \hline ArticleID & $:$ & 5010 \\
\hline \hline ArticleDOI & $:$ & $10.1186 /$ gb-spotlight-20041019-01 \\
\hline \hline ArticleCitationID & $:$ & spotlight-20041019-01 \\
\hline \hline ArticleSequenceNumber & $:$ & 73 \\
\hline \hline ArticleCategory & $:$ & Research news \\
\hline \hline ArticleFirstPage & $:$ & 1 \\
\hline \hline ArticleLastPage & $:$ & 3 \\
\hline \hline & & RegistrationDate : 2004-10-19 $\quad: \quad 2004-10-19$ \\
ArticleHistory & $:$ & OnlineDate \\
\hline \hline ArticleCopyright & $:$ & BioMed Central Ltd2004 \\
\hline \hline ArticleGrants & $:$ & \\
\hline \hline ArticleContext & $:$ & 130595511 \\
\hline \hline
\end{tabular}


Researchers report in the online edition of Proceedings of the National Academy of Sciences this week that they have discovered nearly 30 alternative splicing regulators in Drosophila - nearly triple the number previously known - using a novel RNA interference (RNAi) screen (Proc Natl Acad Sci 2004, DOI:10.1073/pnas.0406999101).

"Most people in the splicing regulation field, including myself, have thought that splicing is regulated by RNA binding proteins that are not components of the spliceosome and that they do so by binding to the RNA where they either enhance or prevent the spliceosome from recognizing the regulated exon. The implications of our findings are that alternative splicing does not need to be regulated by these auxiliary proteins," author Brenton Graveley at the University of Connecticut Health Center in Farmington told The Scientist. "This does not mean that splicing is not regulated by auxiliary splicing factors, but rather seems to be a previously unrealized mechanism by which splicing can be regulated."

Alternative splicing, which generates multiple mRNAs from a single pre-mRNA by joining exons together in different patterns, is thought to be regulated by nonspliceosomal RNA binding proteins that modulate the association of core components of the spliceosome with the pre-mRNA. While genome sequencing projects have revealed how widespread alternative splicing is across many organisms - 74\% of human genes and $50 \%$ of fly genes encode alternatively spliced mRNAs - Graveley was "mystified" about how few alternative splicing regulators were known, noting only about 15 identified so far in Drosophila and only a few more in humans.

So Graveley and colleagues designed an RNAi screen in cultured Drosophila cells, creating doublestranded RNAs (dsRNAs) targeted against 250 proteins that contained known RNA-binding motifs or were spliceosomal components. Four days after the dsRNAs were administered, reverse transcription was used on the total RNA, polymerase chain reaction (PCR) was used to amplify alternatively spliced regions, and PCR products were analyzed by PAGE or single-stranded conformation polymorphism gel electrophoresis. The researchers focused on the effect these dsRNAs had on the alternative splicing of three functionally diverse genes, dAdar, paralytic (para), and Dscam. Each dsRNA that significantly affected at least one alternative exon was considered a positive and was repeated in a second round of screening.

Of the 250 proteins targeted, 47 had specific effects on the alternative splicing of at least one exon, 26 of which were not previously implicated in alternative splicing. Each dsRNA that tested positive in the first round of screening yielded qualitatively similar finds in the second screen. Unexpectedly, while most of the regulators identified are nonspliceosomal RNA-binding proteins, the screen revealed that depleting concentrations of 13 spliceosomal components resulted in specific changes in alternative splicing.

"Although this work was done in Drosophila cells, it should be possible to do similar studies in human cells," Graveley said.

The study "represents a technical tour de force," said Mariano Garcia-Blanco at Duke University in Durham, NC, who did not participate in it. "A lot of people wanted to see how they can apply siRNAs to 
their own system," Garcia-Blanco told The Scientist. "This is a lot easier to do in Drosophila than in mammals, but that said, other labs will absolutely pick this up. It's not going to be that difficult."

Garcia-Blanco noted Graveley's team was very careful in saying that although many RNA-binding proteins did not score on their screen, that does not mean they are not alternative splicing factors, and expects that when Graveley's team does perform a genome-wide RNAi survey, factors that did not score on this screen - including proteins outside the 250 studied - might score on the next.

"It certainly proves that RNAi screening can be informative in terms of alternative splicing. It's not surprising many RNA-binding proteins can influence alternative splicing, but the specificity seen was a bit surprising," Tim Nilsen at Case Western Reserve University in Cleveland, who did not participate in this study, told The Scientist. He and Garcia-Blanco both noted the researchers point out that with any functional screen, it's impossible to make a distinction between direct and indirect effects, and therefore not all of the positives might be splicing regulators.

\section{References}

1. Proceedings of the National Academy of Sciences USA, [http://www.pnas.org/]

2. Holding C: RNAi dissects signal pathway Genome Biology, June 24, 2004., [http://genomebiology.com/researchnews/default.asp?arx_id=gb-spotlight-20040624-01]

3. Brenton R. Graveley, [http://genetics.uchc.edu/Faculty/Graveley/Graveley.html]

4. Pallarito K: Fueling the fires of RNA interference The Scientist, September 13, 2004, [http://www.the-scientist.com/yr2004/sep/feature2_040913.html]

5. Mariano Garcia-Blanco, [http://cmb.duke.edu/faculty/garciablanco.html]

6. Tim Nilsen, [http://mstp.cwru.edu/Research/Mentors/mentordisplay.asp?mentor=Tim\%20Nilsen]

This PDF file was created after publication. 